\title{
Outward Foreign Direct Investment and Domestic Investment: the Case of Developing Countries
}

\author{
Ali J. Al-Sadig
}




\title{
IMF Working Paper
}

Middle East and Central Asia Department

\section{Outward Foreign Direct Investment and Domestic Investment: the Case of Developing Countries}

\section{Prepared by Ali J. Al-Sadig ${ }^{1}$}

Authorized for distribution by Ralph Chami

February 2013

\section{This Working Paper should not be reported as representing the views of the IMF.} The views expressed in this Working Paper are those of the author(s) and do not necessarily represent those of the IMF or IMF policy. Working Papers describe research in progress by the author(s) and are published to elicit comments and to further debate.

\begin{abstract}
Over the past two decades, the growth rate of outward foreign direct investment (FDI) from developing and transition economies has increased significantly. Given the role of physical capital accumulation in determining the economic growth rate, it is important to assess how domestic investment responds to such outflows. This study empirically examines the effects of outward FDI on domestic investment in developing countries. Using data from 121 developing and transition economies over the period 1990-2010, the results suggest that FDI outflows negatively impact the rate of domestic investment.
\end{abstract}

JEL Classification Numbers: E22, F21, F23, O16

Keywords: Foreign Direct Investment, Developing Countries, GMM

Author’s E-Mail Address: aalsadiq@imf.org

\footnotetext{
${ }^{1}$ The author would like to thank Ralph Chami and Serhan Cevik for their extensive discussions and helpful comments on the earlier version of this paper. Also, he would like to thank Dragana Ostojic and Nasser Abdul for their comments, and to thank the participants in MCD's Discussion Forum.
} 


\section{Contents}

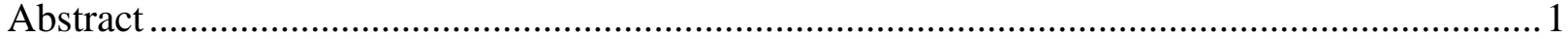

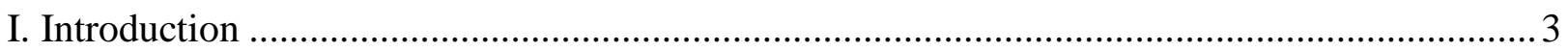

II. Outward FDI from Developing Countries …………..................................................... 4

III. Theoretical Considerations …………......................................................................... 6

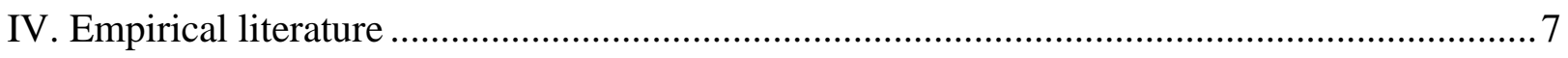

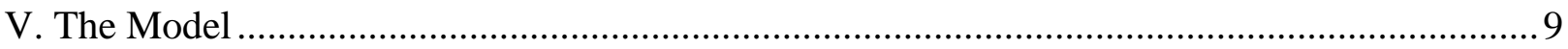

A. Estimation Method .................................................................................................. 11

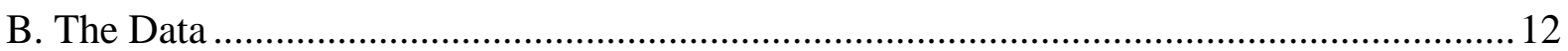

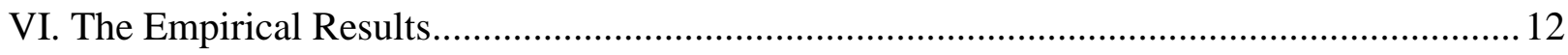

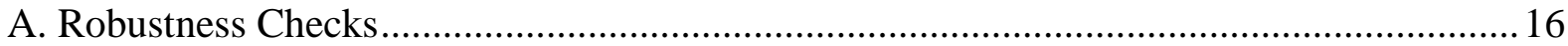

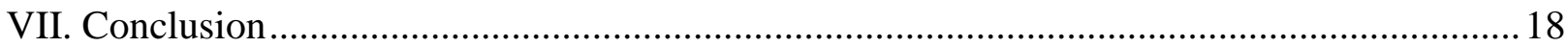

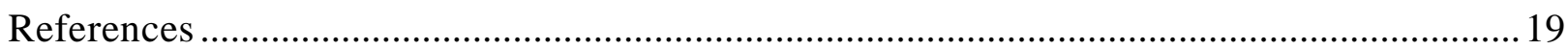

\section{Tables}

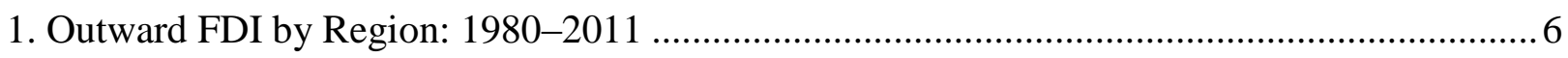

2. Domestic Investment and Capital flows: OLS Regressions ..................................................... 13

3. Domestic Investment and Capital flows: System GMM ...................................................... 15

4. Domestic Investemnt and Capital flows: Poiltical Enviornamnt ...............................................22

5. Domestic Investemnt and Capital flows: Non-linearilty Relations .........................................2 23

6. Domestic Investment and Capital flows: Alternative Estimation Methods ..............................2.24

\section{Figures}

1. FDI outward from Developing Countries: 1980-2011 ……….............................................5

2. Regional FDI Outflows as a share of Developing and Transitions Outflows.............................5 


\section{INTRODUCTION}

Although developed countries remain the leading source of outward foreign direct investment (FDI), developing and transition economies have emerged as an important source of outward FDI since the 1990s. Many multinational enterprises (MNEs) from the developing and transition economies are increasingly undertaking cross-border investment activities through FDI. Between 1980 and 2011, their share of world outward FDI rose from 6.2 percent to 26.9 percent and peaked in 2010 at 31.8 percent. Thus, a question that naturally arises is whether these outflows affect economic activity in home countries.

While the rising levels of outward FDI from developed countries have raised concerns regarding its impact on their domestic investment, little or no attention has been paid to such effects in developing and transition economies. Policymakers in these countries need to assess how domestic investment is affected by FDI outflows; domestic investment determines the rate at which physical capital is accumulated, which subsequently determines the rate of economic growth. Understanding the impact of FDI outflows on domestic investment may therefore be a vital step toward introducing market reforms that can boost domestic investment and enhance growth.

From a theoretical viewpoint, the impact of FDI outflows on the home country's domestic investment may occur through financial markets and product markets. FDI outflows, under the conditions of an imperfect financial market, may raise domestic interest rates by shifting funds out of the home country and consequently making borrowing more difficult for domestic firms. Furthermore, firms seeking to invest abroad, by shifting their production abroad, may reduce domestic exports; such outflows can be viewed as diverting domestic investment. However, if FDI outflows complement the home country's exports through backward and forward production linkages, then such outflows may be seen as a complement to domestic investment. Therefore, because FDI outflows may have positive, negative, or neutral effects on the home country's domestic investment rate, an empirical exercise is necessary to identify the overall effects of such outflows.

The main contribution of this study is that it is a first attempt at focusing on developing and transition economies. The findings of studies on the relationship between outward FDI and domestic investment in developed countries may not apply to developing and transition economies because the effects of such FDI flows may differ in these countries. For example, the effects will differ significantly in countries with abundant savings and other forms of capital from the effects in countries with scarce capital.

In order to empirically disentangle the impact of FDI outflows on domestic investment, this study applies an econometric model based on a modified version of the flexible accelerator model and employs panel data for 121 developing home countries over the period 1990-2010. The model is estimated by the system-Generalized Method of Moments (GMM) to cope with the possible endogeneity of outward FDI. 
The empirical findings show that outward FDI reduces domestic investment in the home country. A one percentage point increase in FDI outflows from the home country leads to a 29 percent decrease in domestic investment as a percentage of GDP. That is, \$10 of outward FDI reduces domestic investment by $\$ 2.9$ in the short run and $\$ 7.8$ in the long run. On the other hand, the empirical results show that inward FDI crowds in the host countries' domestic investment. A one percentage point increase in FDI inflows stimulates domestic investment by about 55 percent.

The rest of the paper is organized as follows. Section II discuses the trend in outward FDI from developing and transition economies. Section III discusses the theoretical considerations on the relations between outward FDI and domestic investment. Section IV surveys the empirical literature. Section V presents the econometric model and discusses the estimation method. Section VI presents the empirical results, and Section VII concludes.

\section{OUTWARD FDI FROM DEVELOPING COUNTRIES}

While developed countries remain the leading source of outward FDI, developing and transition economies have emerged as important sources of outward FDI since the 1990s. Many MNEs from the developing and transition economies are increasingly undertaking cross-border investment activities through FDI. Between 1980 and 2011, their share of world outward FDI rose from 6.2 percent to 26.9 percent and peaked in 2010 at 31.8 percent. Figure 1 shows that the share of developing and transition economies in world FDI outflows increased over the period 1980-2011. In the 1980s, developing and transitional countries' share of world outward FDI peaked at 9.6 percent in 1982; this share increased further in the early 1990s to reach 16.7 percent in 1994. It declined significantly between 1998 and 2001, but grew steadily afterward to a peak of 31.8 percent in 2010 . 
Figure 1. Outward FDI from Developing Countries: 1980-2011

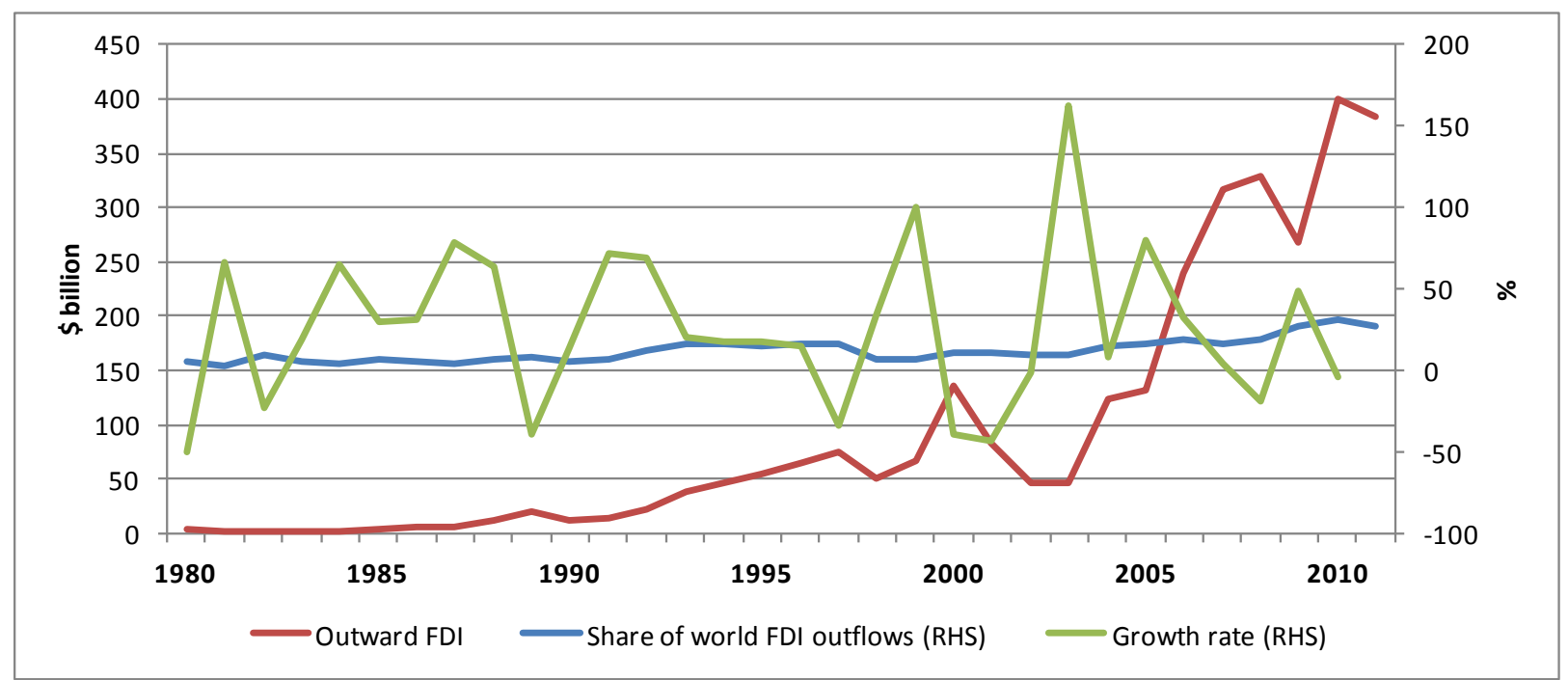

Source: United Nations, World Investment Report, 2012.

The distribution of outward FDI from developing and transition economies is relatively concentrated. As shown in Figure 2, in 2011, about 61.4 percent of total FDI outflows from developing and transition economies originated from Asian countries, 21.8 percent from Latin America and the Caribbean, and 16 percent from transition economies. In fact, Asian countries emerge as the largest source countries among the developing and transition economies since 1985. On the other hand, growth in FDI outflows from the Africa region was much less than from other developing regions (see Table 1).

Figure 2. Regional FDI Outflows as a Share of Developing and Transition Country Outflows

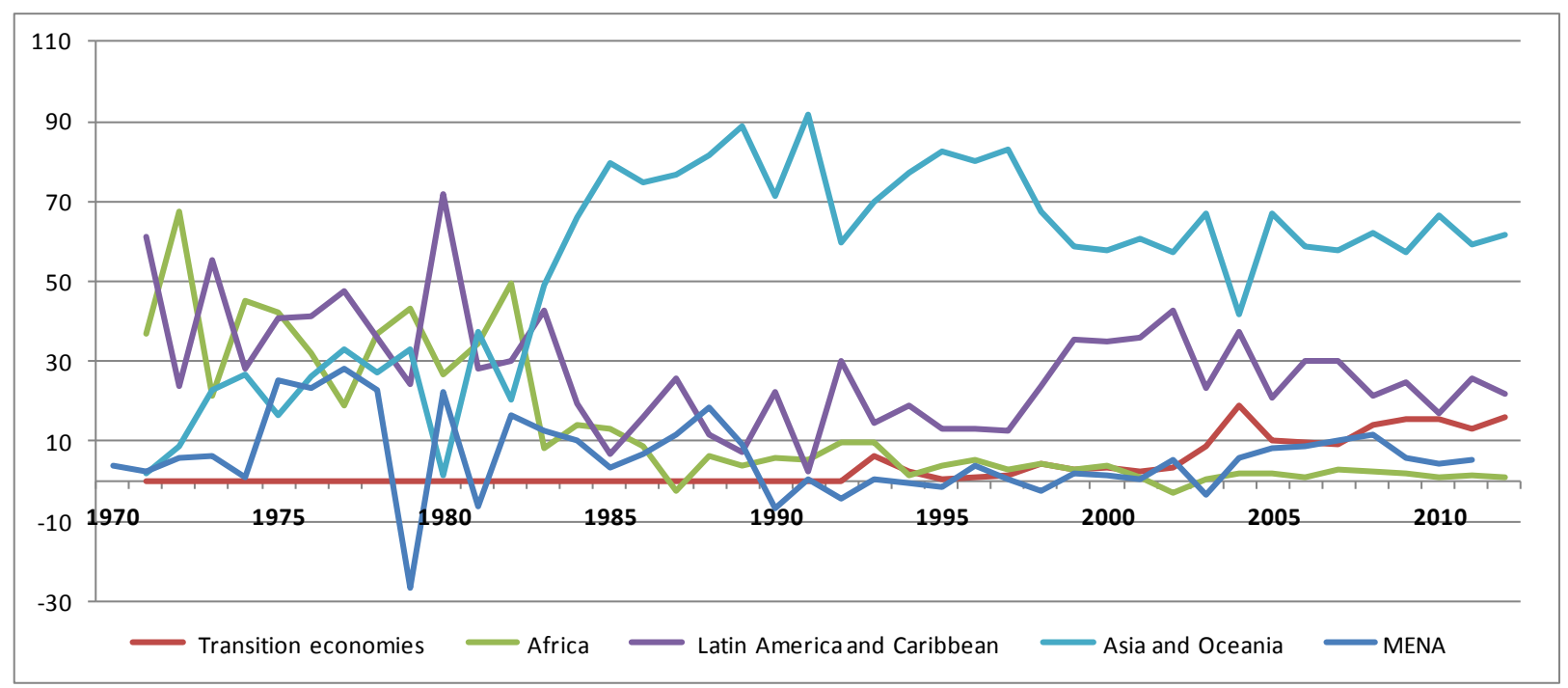

Source: United Nations, World Investment Report, 2012. 
Table 1. Outward FDI by Region: 1980-2011

(Billions of current U.S. dollars)

\begin{tabular}{lccccccccc}
\hline Region & $\mathbf{1 9 8 0 s}$ & $\mathbf{1 9 9 0 s}$ & $\mathbf{2 0 0 0 - 0 5 *}$ & $\mathbf{2 0 0 6}$ & $\mathbf{2 0 0 7}$ & $\mathbf{2 0 0 8}$ & $\mathbf{2 0 0 9}$ & $\mathbf{2 0 1 0}$ & $\mathbf{2 0 1 1}$ \\
\hline World & 93.5 & 418.8 & 814.6 & 1415.1 & 2198.0 & 1969.3 & 1175.1 & 1451.4 & 1694.4 \\
Advanced Countries & 87.6 & 372.7 & 711.7 & 1152.0 & 1829.6 & 1580.8 & 857.8 & 989.6 & 1237.5 \\
Developing Economies & 5.9 & 44.9 & 94.6 & 239.3 & 316.9 & 328.1 & 268.5 & 400.1 & 383.8 \\
$\quad$ Africa & 0.5 & 1.9 & 0.8 & 8.2 & 9.3 & 7.9 & 3.2 & 7.0 & 3.5 \\
$\quad$ Latin America & 1.1 & 9.9 & 32.2 & 79.7 & 79.3 & 97.0 & 54.3 & 119.9 & 99.7 \\
$\quad$ Asia and Oceania & 4.3 & 33.1 & 61.6 & 151.4 & 228.2 & 223.2 & 211.0 & 273.2 & 280.6 \\
MENA & 0.69 & 0.08 & 3.9 & 23.0 & 37.8 & 44.4 & 19.2 & 20.0 & 24.9 \\
Transition Economies & 0.0 & 1.2 & 8.3 & 23.7 & 51.6 & 60.5 & 48.8 & 61.6 & 73.1 \\
\hline
\end{tabular}

Note: *Annual Average, Source: UNCTAD.

\section{Theoretical Considerations}

The effects of outward FDI on domestic investment may vary from one home country to another, depending on firms' underlying motives for investing abroad and on the characteristics of each home country's economy. For example, because capital outflows would transfer part of private domestic savings abroad, the effects of such outflows in countries with abundant savings and other forms of capital will differ significantly from the effects in countries with scarce capital.

Stevens and Lipsey (1992) identify two mechanisms through which FDI outflows may affect the home country's domestic investment. The first is through domestic financial markets. Firms seeking to invest abroad would transfer part of their capital abroad, which means that part of private domestic savings is shifted out of the home country. Thus, under conditions of an imperfect financial market and scarcity of financial resources, the financial liquidity available to finance new investment activities is reduced, and domestic firms will face difficulties in raising funds in the domestic financial markets. Therefore, based on this channel, FDI outflows discourage the home country's domestic investment, especially if firms finance their overseas activities internally. 
The second mechanism is when firms affect product markets by shifting their production abroad. Whereas the impact of the first channel is clear, the net impact of FDI outflows through shifting production abroad largely depends on the motives for investing abroad. The literature identifies three: efficiency-seeking, market-seeking, and strategic asset-seeking (Dunning, 1993). ${ }^{2}$ The first motive occurs when firms seek to increase their efficiency by transferring production facilities to countries with relatively cheap inputs. It is also called vertical FDI as it involves relocating parts of the production chain to the host country and is viewed as a complement to trade. In this case, there is no initial reduction in domestic production, and it may be that outward FDI stimulates the rate of domestic investment through firms exporting capital and intermediate goods (Hejazi and Pauly, 2003). The second motive aims to serve the host country's domestic and neighboring markets. The effects of this kind of FDI are ambiguous: they depend on whether outward FDI displaces exports. ${ }^{3}$ On the one hand, outward FDI in services would have either neutral or positive effects on the rate of domestic investment because FDI would not substitute exports (Hejazi and Pauly, 2003). On the other hand, if outward FDI displaces exports or a firm moves its production facilities from home to a host country, then it is clear that outward FDI would reduce domestic investment. However, although FDI may displace exports of finished products, it may also promote exports of intermediate products from the parent or from other domestic firms in the home country to the firm's foreign affiliate; the net impact is not clear. The last motive, strategic asset-seeking, aims to obtain assets, unavailable at home, that may be important to firms' long-term strategy. This type of FDI may have positive effects on domestic investment, because access to new technologies and knowledge may help firms increase their productivity and take on new activities in the home economy. Thus, based on the above two channels, the impact of FDI outflows on the home country's domestic investment may be positive, negative, or neutral.

\section{EMPIRICAL LITERATURE}

The empirical literature on outward FDI and domestic investment in developed countries can be grouped into two strands. The first uses aggregated macro-level data and the other uses firmlevel data. The results provided by both strands are inconclusive. Some studies find that outward FDI reduces the country's rate of domestic investment, while others find that outward FDI stimulates domestic investment, and some find no effect.

Feldstein (1995), using data from OECD countries for the 1970s and 1980s, finds that each dollar of outward FDI reduces domestic investment by about one dollar, and that the results are robust to different specifications. Andersen and Hainaut (1998), using data for the United States, Japan, Germany, and the United Kingdom spanning from the 1960s until the 1990s,

\footnotetext{
${ }^{2}$ Dunning (1993) identifies four motives behind investing abroad; natural resource seeker, market seeker, efficiency seeker, and strategic seeker. However, a natural resource seeker may be classified as anefficiency seeker as well, and so the effects of this type are not discussed explicitly.

${ }^{3}$ This is related to the unsettled question of whether FDI complements or substitutes exports.
} 
reach the same results as in Feldstein. In each country, outward FDI is found to reduce domestic investment, though the relation may not necessarily be a dollar-for-dollar correspondence. Herzer and Schrooten (2007) conduct a similar analysis for the United States and Germany, and find that, in Germany, outward FDI has a negative long-run effect on domestic investment while the short-run effect is positive. For the United States, they find that outward FDI has a positive long-run effect on domestic investment. Desai et al. (2005) use two different approaches to test the relationship between outward FDI and domestic investment. In the first approach, they use similar specifications to Feldstein's but with a much broader sample of OECD countries for the 1980s and 1990s, while in the second approach they use time-series data on capital expenditures of U.S. MNEs. The findings of the two approaches are different. In the first, they find that outward FDI from OECD countries reduces domestic investment; in the second approach, they find that higher capital expenditure by the U.S. MNEs abroad is associated with higher domestic capital expenditure by the same firms, suggesting that foreign and domestic investment are complements rather than substitutes. Sauramo (2008) analyzes the relationship between outward FDI and domestic investment using macroeconomic data for Finland over the period 19652006. He finds that outward FDI decreases the domestic investment rate by a one-to-one ratio.

Stevens and Lipsey (1992), using firm-level data covering the domestic and foreign operations of seven U.S. MNEs for a period of 16 to 20 years, show that there is a strong positive correlation between FDI outflows and domestic investment. Finally, Hejazi and Pauly (2003), employing data at the industry level for Canada over the period 1984-95, find that the impact of outward FDI varies according to the investment partner. For example, Canada's outward FDI to the United States increases Canadian domestic investment, outward FDI to the rest of the world reduces Canadian domestic investment, and outward FDI to the United Kingdom has a neutral effect.

While those studies have applied different methodologies and different datasets, they share a common empirical methodological problem, the endogeneity of outward FDI, which may have a substantial impact on the estimated effects of outward FDI. That is, there is a two-way relationship between the rate of domestic investment and outward FDI. Feldstein (1995: p. 55) noted that "a country that offers a 'good environment' for domestic investment is also likely to attract more inbound FDI and may also experience less outbound FDI." For example, the factors that may influence firms to move abroad, such as market and trade conditions, production costs, domestic business conditions, and home government policies may also determine the rate of domestic investment. However, failing to find a proper instrumental variable for inward and outward FDI, Feldstein was unable to estimate his model by means of Instrumental Variable (IV) estimators. Instead, to reduce the possible bias in the estimated FDI coefficients, he includes additional variables that may be correlated with both domestic investment and outward FDI.

The present study overcomes this econometric problem in the following ways. First, the systemGMM estimator is used to control for the possible simultaneous determinants of the dependent 
variable and some of the independent variables,. Second, the study controls for the unobserved country-specific factors by employing panel data analysis. With panel data use, the sample size is much larger than would be the case if only time-series or cross-sectional data were employed, and so allows more degrees of freedom and more efficiency, resulting in more reliable estimates of the regression parameter (Baltagi, 1995, p. 3).

\section{THE MODEL}

The study employs a dynamic panel model to estimate simultaneously the short- and long-run effects of outward FDI on the rate of domestic investment in the home countries. In order to achieve this aim, the "partial adjustment" model is applied. The determinants of domestic investment equation can be described as follows:

$$
I_{i, t}^{*}=x_{i, t}^{\prime} \boldsymbol{\beta}+\varepsilon_{i, t}
$$

where $I^{*}{ }_{i, t}$ is the desired level of domestic investment which is assumed to depend on the country's economic conditions $x$, and $\varepsilon_{i, t}$ is the usual random disturbance. Because the desired domestic investment $\left(I_{i, t}^{*}\right)$ is not observable, what is actually observed is the actual level $\left(I_{i, t}\right)$, and the relationship between the desired investment level and actual level is characterized by the partial adjustment behavior of domestic investment, as follows:

$$
I_{i, t}-I_{i, t-1}=\theta\left(I^{*}{ }_{i, t}-I_{i, t-1}\right)
$$

Where $I_{i, t-1}$ is one year lagged actual domestic investment in country $i, \theta$ is a parameter with a range as $(0,1]^{4}$ which captures the speed of adjustment toward the desired domestic investment level. The larger the value of $\theta$, the faster the adjustment. According to Equation (2), the percentage change occurring during one time period is proportional to the difference between the desired domestic investment in the current period and the actual domestic investment in the previous period. By rearranging equation (2), we get:

$$
I_{i, t}=(1-\theta) I_{i, t-1}+\theta I_{i, t}^{*}
$$

Inserting Equation (1) into (3) and rearranging yields, the estimated dynamic panel specification becomes:

$$
I_{i, t}=\gamma I_{i, t-1}+x_{i, t}^{\prime} \lambda+v_{i, t}
$$

\footnotetext{
${ }^{4}$ For the adjustment process to be stable, $\theta$ must be less than 1 .
} 
where $\gamma=(1-\theta)$ and $\lambda=\theta \beta$. The new error term is now given by $v_{i t}=\theta \varepsilon_{i t}$. If there is a positive feedback effect, the coefficient of the lagged dependent variable $\gamma$ should be positive (i.e., past domestic investment stimulates the current rate of domestic investment).

We assume that the desired level of investment depends on the following factors: (i) the accelerator effect, (ii) macroeconomic instability, (iii) the degree of openness, (iv) the level of saving, and (v) financial development. Therefore, the benchmark investment equation may be written as follows:

$$
\begin{gathered}
\mathrm{DI}_{i, t}=\alpha_{0}+\alpha_{1} \mathrm{DI}_{i, t-1}+\alpha_{2} \mathrm{OFDI}_{i, t}+\alpha_{3} \mathrm{IFDI}_{i, t}+x_{i, t}^{\prime} \boldsymbol{\beta}+\varepsilon_{i, t} \\
\varepsilon_{i, t}=\eta_{i}+v_{i, t} \quad i=1,2 \ldots \mathrm{N} \text { and } t=1,2, \ldots T
\end{gathered}
$$

where $i$ is the home country, $t$ is the time, $\alpha_{s}$ and $\boldsymbol{\beta}$ are unknown parameters to be estimated, $\eta$ is the unobserved country-specific effects, and $\varepsilon$ is the usual random disturbance term. The dependent variable DI is domestic investment measured by domestic investment as a share of GDP.

The primary interest of the current analysis is the sign and magnitude of the estimated coefficient of outward FDI (OFDI) (i.e., $\alpha_{1}$ ), althoughthe effects of inward FDI (IFDI) are also noteworthy. Equation (5) estimates the short-run effects of level of FDI outflows on the country's domestic investment. The corresponding long-run effects can be easily derived from the estimated short-run effect and the estimated value of $\gamma$.

The choice of the control variables is determined using existing empirical work. The past value of domestic investment (DI) is expected to have a positive effect, because it may be a sign of a good investment climate (a positive feedback effect). Level of economic activity is captured by the growth rate of real GDP (RGDPG) and the expected effect is positive. Some empirical studies find that the growth rate of real GDP is the most important factor driving domestic investment (Wai and Wong, 1982; Blejer and Khan, 1984; Greene and Villanueva, 1991). ${ }^{5}$ Because the country's economic stability is seen to play an important role in economic progress, macroeconomic instability, causing uncertainty, is considered to have negative effects on domestic investment. Macroeconomic instability is captured by the inflation rate (INF) and the expected sign of the coefficient is negative (Greene and Villanueva, 1991; Servén and Solimano, 1993; Oshikoya, 1994; and Ndikumana, 2000). Domestic saving plays an important role in financing a large share of domestic investment in most developing countries (Agènor, 2004: p. 28). Feldstein and Horioka (1980) showed that savings and investment are highly positively correlated. Thus, gross national saving (Saving) is used to control for this factor. Well-developed financial markets increase the quantity of credit available for private investors and so stimulate private investment (Ndikumana, 2000). Two different proxies are used for the

\footnotetext{
${ }^{5}$ Ideally, one may need to control for the real interest rate to capture the cost of capital, but data are not available for the time span employed in the current analysis.
} 
level of financial development. Broad money supply (M2) and credit to private sector (Credit) are used as proxies for the level of financial development, with the expected effect to be positive. Some empirical studies also highlighted the impact of trade openness on domestic investment. Trade openness (Openness) may positively affect domestic investment through technology and knowledge spillovers. However, it may also exert a negative effect on the rate of domestic investment if consumers prefer imported products (Ndikumana, 2000).

\section{A. Estimation Method}

In order to evaluate the effects of outflows of FDI on the rate of domestic investment in the home country, this study uses the system-GMM estimator developed by Arellano and Bover (1995) and Blundell and Bond (1998), which yields consistent and efficient estimates by addressing two important econometric problems.

First, in the presence of the lagged dependent variable on the right-hand side of the equation and the time-invariant country-specific, the fixed-effects estimator would yield inconsistent estimates because of the correlation between the lagged dependent variable and the error terms. The system-GMM estimator enables controlling for the unobserved country-specific factors; the estimated coefficients would then not be subject to bias from an omitted variable. Second, FDI inflows and outflows are likely to be endogenous and determined jointly with the rate of domestic investment. That is, there is a two-way relationship between domestic investment and FDI flows. While it is difficult to find a proper instrument for the FDI flows, the system-GMM estimator helps to solve the endogeneity problem by using a series of internal instrumental variables based on lagged values of the dependent and independent variables. As a first step, the time-invariant country-specific factors are removed by taking the first differences of Equation (5).

$$
\Delta I_{i, t}=\alpha_{1} \Delta I_{i, t-1}+\alpha_{2} \Delta \mathrm{IFDI}_{i, t}+\alpha_{3} \Delta \mathrm{OFDI}_{i, t}+\Delta x_{i, t}^{\prime} \boldsymbol{\beta}+\Delta v_{i, t}
$$

However, besides the possible endogeneity of FDI variables, the error terms in Equation (6) are still correlated with the lagged dependent variable. The system-GMM estimator solves the correlation problem by using a set of internal instruments based on the assumption of no second-order serial correlation in the first-differenced idiosyncratic errors, and the independent variables are weakly exogenous. In this case the lagged levels of the dependent variable may be used as instrument for $\Delta I_{i, t-2 .}{ }^{6}$

However, as pointed out by Blundell and Bond (1998), the GMM estimator just outlined (known as the first-differenced GMM estimator, developed by Arellano and Bond (1991)) has been found to have poor finite sample bias and poor precision when the lagged levels of the

\footnotetext{
${ }^{6}$ For the other variables, $\operatorname{IFDI}_{i, t-2}$ may be used as instrument for $\Delta \operatorname{IFDI}_{i, t-1}, \operatorname{OFDI}_{i, t-2}$ for $\Delta \operatorname{OFDI}_{i, t-1,1}$ and $x_{i, t-1}$ for $\Delta x_{i, t}^{\prime}$.
} 
series are weak instruments for the first differences, especially for variables that are close to a random walk. The system GMM overcomes this issue by combining in one system the regression in differences with the regression in levels under the assumption that there is no correlation between the differences of the right-hand side variables and the unobserved countryspecific effects. In this case, the instruments for the regression in differences are lagged levels as in the original estimator, while those for the regression in levels are the lagged differences of the corresponding variables.

For testing the validity of the moment conditions, the system-GMM estimator checks for the validity of instruments using the Sargan/Hansen test for over-identifying restrictions, and for a second-order serial correlation of the differenced error term.

\section{B. The Data}

This study employs unbalanced panel data for 121 countries over the period 1990-2010. The dependent variable is defined as domestic investment as a percentage of GDP. Data on the dependent variable, the growth rate of real GDP, the inflation rate, and gross national saving come from the IMF's World Economic Outlook database (2012). Data on the sum of exports and imports to GDP, Schooling, credit to private sector, broad money supply (M2) and real effective exchange rate come from the World Bank's World Development Indicators (2012). Data on institutional quality come from International Country Risk Guide, Political Risk Groups. Data on political risk come from Gibney, Cornett, and Wood (2012). Finally, FDI data are measured in current U.S. dollars and come from UNCTAD's World Investment Report (2012). With the exception of real GDP growth rate and inflation rate, all variables are deflated by GDP in current U.S. dollars.

\section{The EMPIRICAL RESUlts}

As mentioned above, existing studies employed cross-sectional regressions to test the relationship between outward FDI and domestic investment. Thus, as an initial step, the present study begins with the cross-sectional analysis, in order to confirm previous studies, using averages for the entire period 1990-2010. The OLS cross-sectional regression results presented in the first column of Table 1 are based on Feldstein's (1995) specification, using the full sample. Column 2 reports the results after excluding developed countries from the sample. As can be seen from those columns, the estimated coefficient on FDI outflow is negative and statistically significant at the 1 percent level. A one percentage point increase in FDI outflows reduces domestic investment by about 97 percent. In dollar terms, $\$ 10$ outflows reduce domestic investment by about $\$ 9.7$. This result is very close to those studies which find a dollar-for-dollar negative relation between foreign and domestic investment. Moreover, the significance of the negative impact remains unchanged, even after controlling for other independent variables. 
Table 2. Domestic Investment and Capital Flows: OLS Regressions

Dependent Variable : Domestic Investment /GDP: 1990-2010

\begin{tabular}{|c|c|c|c|c|c|c|}
\hline Independent Variables & (1) & (2) & (3) & (4) & (5) & (6) \\
\hline FDI outflows/GDP & $\begin{array}{l}-0.92^{*} \\
\mathbf{( - 5 . 4 6 )}\end{array}$ & $\begin{array}{l}-0.97^{*} \\
\mathbf{( - 3 . 9 3 )}\end{array}$ & $\begin{array}{l}-0.83^{*} \\
\mathbf{( - 3 . 7 6 )}\end{array}$ & $\begin{array}{l}-0.76^{*} \\
\mathbf{( - 3 . 0 9 )}\end{array}$ & $\begin{array}{l}-0.76^{*} \\
\mathbf{( - 3 . 0 7 )}\end{array}$ & $\begin{array}{l}-0.85^{*} \\
\mathbf{( - 3 . 2 7 )}\end{array}$ \\
\hline FDI inflows/GDP & $\begin{array}{l}0.96^{*} \\
\mathbf{( 5 . 4 2 )}\end{array}$ & $\begin{array}{c}1.0^{*} \\
\mathbf{( 5 . 4 4 )}\end{array}$ & $\begin{array}{c}0.83^{*} \\
\mathbf{( 4 . 8 3 )}\end{array}$ & $\begin{array}{c}0.87^{*} \\
\mathbf{( 4 . 4 8 )}\end{array}$ & $\begin{array}{c}0.91^{*} \\
\mathbf{( 4 . 5 1 )}\end{array}$ & $\begin{array}{c}0.89^{*} \\
\mathbf{( 4 . 3 2})\end{array}$ \\
\hline Saving/GDP & $\begin{array}{c}0.42^{*} \\
\mathbf{( 5 . 5 3 )}\end{array}$ & $\begin{array}{c}0.42^{*} \\
\mathbf{( 5 . 1 7 )}\end{array}$ & $\begin{array}{c}0.38^{*} \\
4.80\end{array}$ & $\begin{array}{c}0.39^{*} \\
\mathbf{( 4 . 9 0 )}\end{array}$ & $\begin{array}{c}0.39^{*} \\
\mathbf{( 4 . 9 6 )}\end{array}$ & $\begin{array}{c}0.38^{*} \\
(\mathbf{4 . 7 3})\end{array}$ \\
\hline RGDPG & & & $\begin{array}{c}0.47^{*} \\
(\mathbf{2 . 3 1})\end{array}$ & $\begin{array}{l}0.46^{*} \\
(\mathbf{2 . 2 3})\end{array}$ & $\begin{array}{l}0.42^{* *} \\
(\mathbf{1 . 9 7})\end{array}$ & $\begin{array}{l}0.45^{* *} \\
(\mathbf{2 . 0 2})\end{array}$ \\
\hline Openness & & & & $\begin{array}{c}-0.01 \\
\mathbf{( - 0 . 4 2 )}\end{array}$ & $\begin{array}{c}-0.01 \\
\mathbf{( - 0 . 6 0 )}\end{array}$ & $\begin{array}{c}-0.01 \\
\mathbf{( - 0 . 6 1 )}\end{array}$ \\
\hline Inflation & & & & & $\begin{array}{l}-0.006 \\
\mathbf{( - 1 . 5 9 )}\end{array}$ & $\begin{array}{l}-0.005 \\
\mathbf{( - 1 . 3 7 )}\end{array}$ \\
\hline M2/GDP & & & & & & $\begin{array}{c}0.01 \\
(\mathbf{0 . 8 4})\end{array}$ \\
\hline Constant & $\begin{array}{c}12.0^{*} \\
\mathbf{( 7 . 8 8})\end{array}$ & $\begin{array}{c}11.7^{*} \\
\mathbf{( 7 . 3 6 )}\end{array}$ & $\begin{array}{l}11.1^{*} \\
\mathbf{( 7 . 9 4 )}\end{array}$ & $\begin{array}{c}11.4^{*} \\
\mathbf{( 6 . 9 6 )}\end{array}$ & $\begin{array}{c}11.8^{*} \\
\mathbf{( 6 . 8 6 )}\end{array}$ & $\begin{array}{c}11.5^{*} \\
(6.71)\end{array}$ \\
\hline No. of Observations & 143 & 122 & 122 & 122 & 122 & 122 \\
\hline R-Squared & 0.55 & 0.56 & 0.55 & 0.58 & 0.59 & 0.59 \\
\hline VIF & 1.21 & 1.19 & 1.39 & 1.77 & 1.68 & 1.77 \\
\hline
\end{tabular}

Notes:

In column 1, the whole sample is used. In columns 2-6, developing and transition economies only. Robust $t$-statistics are in parentheses. Multicollinearity has been tested by the creation of Variance Inflation Factors (VIF). $*, * *$, and $* * *$ indicate statistical significance at 1 percent, 5 percent and 10 percent levels, respectively.

Indeed, the cross-sectional regressions show that there is a strong negative correlation between a country's FDI outflows and its domestic investment. Yet the cross-sectional analysis ignores time-series fluctuations and only tests for the long-run relationship between FDI outflows and domestic investment. Moreover, such a method cannot control for unobservable countryspecific effects that may vary across countries and that may be correlated with FDI outflows.

Table 2 contains the principal empirical results. The model estimations reported under columns 1 and 2 estimate the effects of outward and inward FDI on the home country's domestic investment using the full sample (developed countries, developing and transition economies). 
Columns 3-6 estimate the model for a sample containing only developing and transition economies. Even-numbered models are estimated with time-specific effects. It should be noted that Equation (6) estimates the short-run effects of the independent variables: for example, the short-run effect of outward FDI is merely $\alpha_{3}$. To derive the long-run effects of FDI, the estimated short-run effects and the estimated coefficient of the lagged dependent variable (i.e., the value of $\beta_{1}$ ) are used.

As is apparent from the results presented under column 1, the estimated coefficient for the outward FDI variable is negative and statistically significant at the 1 percent level, which is consistent with the findings of previous studies (Feldstein, 1995; and Desai et al. 2005). Also, even after advanced countries are excluded from the sample, this result still holds. The estimated coefficient is quite stable and is not sensitive to different model specifications. The results reported under column 4 show that outward FDI has negative impacts on domestic investment. In the short run, a one percentage point increase in outward FDI as a percentage of GDP causes a reduction of about 29 percent in domestic investment as a percentage of GDP, while in the long run the effect is about 73 percent. In dollar terms, $\$ 10$ of outward FDI from the home country reduces domestic investment by about $\$ 2.9$ in the short run and by about $\$ 7.3$ in the long run.

Conversely, the empirical results show that FDI inflows crowd in domestic investment. The estimated coefficient of the inward FDI reported under column 4 is positive and robustly significant at the 1 percent level, suggesting that FDI inflows stimulate domestic investment. A one percentage point increase in inward FDI as a percentage of GDP increases the rate of domestic investment by about 55 percent in the short run. This finding is consistent with the findings of Van Loo (1977), Bosworth and Collins (1999), Agosin and Mayer (2000), Xu and Wang (2007), and AlSadig (2012). 
Table 3. Domestic Investment and Capital Flows: System-GMM

Dependent variable: Domestic Investment/GDP: 1990-2010

\begin{tabular}{|c|c|c|c|c|c|c|}
\hline \multirow{2}{*}{ Independent variables } & \multicolumn{2}{|c|}{ Whole Sample } & \multicolumn{4}{|c|}{ Developing Countries } \\
\hline & (1) & $(2)$ & (3) & (4) & $(5)$ & (6) \\
\hline lagged (Dependent variable) & $\begin{array}{l}0.63^{*} \\
(\mathbf{6 . 0 8})\end{array}$ & $\begin{array}{l}0.62^{*} \\
(\mathbf{5 . 4 5 )}\end{array}$ & $\begin{array}{l}0.62^{*} \\
\mathbf{( 5 . 8 7 )}\end{array}$ & $\begin{array}{l}0.60^{*} \\
\mathbf{( 5 . 3 7 )}\end{array}$ & $\begin{array}{c}0.62^{*} \\
(\mathbf{7 . 6 5})\end{array}$ & $\begin{array}{l}0.62^{*} \\
(\mathbf{5 . 4 6 )}\end{array}$ \\
\hline FDI outflows/GDP & $\begin{array}{l}-0.23^{*} \\
(-\mathbf{3 . 2 5})\end{array}$ & $\begin{array}{l}-0.22^{*} \\
(-\mathbf{3 . 3 2})\end{array}$ & $\begin{array}{l}-0.29^{*} \\
\mathbf{( - 2 . 5 0 )}\end{array}$ & $\begin{array}{l}-0.29^{*} \\
(-2.65)\end{array}$ & $\begin{array}{l}-0.29^{*} \\
(-2.67)\end{array}$ & $\begin{array}{l}-0.27^{*} \\
(-2.34)\end{array}$ \\
\hline FDI inflows/GDP & $\begin{array}{c}0.49^{*} \\
\mathbf{( 3 . 3 9 )}\end{array}$ & $\begin{array}{l}0.49^{*} \\
\mathbf{( 3 . 4 1 )}\end{array}$ & $\begin{array}{l}0.55^{*} \\
\mathbf{( 3 . 6 3 )}\end{array}$ & $\begin{array}{l}0.55^{*} \\
\mathbf{3 . 8 1})\end{array}$ & $\begin{array}{l}0.54^{*} \\
\mathbf{( 3 . 5 1 )}\end{array}$ & $\begin{array}{l}0.53^{*} \\
(\mathbf{3 . 9 8})\end{array}$ \\
\hline Openness & $\begin{array}{l}-0.04^{*} \\
(-\mathbf{3 . 5 0})\end{array}$ & $\begin{array}{l}-0.04^{*} \\
(-2.90)\end{array}$ & $\begin{array}{l}-0.04^{*} \\
(-\mathbf{3 . 0 8})\end{array}$ & $\begin{array}{l}-0.03^{*} \\
(-\mathbf{2 . 3 3})\end{array}$ & $\begin{array}{l}-0.04^{*} \\
(-\mathbf{3 . 1 3})\end{array}$ & $\begin{array}{l}-0.03^{* *} \\
(\mathbf{- 1 . 9 5 )}\end{array}$ \\
\hline RGDPG & $\begin{array}{l}0.13^{*} \\
(\mathbf{3 . 0 5})\end{array}$ & $\begin{array}{l}0.14^{*} \\
\mathbf{( 4 . 3 2 )}\end{array}$ & $\begin{array}{l}0.11^{*} \\
(\mathbf{2 . 7 3})\end{array}$ & $\begin{array}{l}0.13^{*} \\
(\mathbf{4 . 2 0})\end{array}$ & $\begin{array}{l}0.11^{*} \\
(\mathbf{2 . 8 7})\end{array}$ & $\begin{array}{l}0.13^{*} \\
(\mathbf{3 . 1 5})\end{array}$ \\
\hline $\mathrm{M} 2 / \mathrm{GDP}$ & $\begin{array}{c}0.02 \\
\mathbf{( 1 . 5 8 )}\end{array}$ & $\begin{array}{c}0.01 \\
\mathbf{0 . 4 9 0}\end{array}$ & $\begin{array}{c}0.01 \\
\mathbf{0 . 8 5 0}\end{array}$ & $\begin{array}{l}0.001 \\
\mathbf{( 0 . 0 6 )}\end{array}$ & $\begin{array}{c}0.01 \\
(\mathbf{0 . 8 2})\end{array}$ & $\begin{array}{l}0.003 \\
(\mathbf{0 . 1 5})\end{array}$ \\
\hline Inflation & $\begin{array}{l}-0.002 \\
\mathbf{( - 1 . 5 9 )}\end{array}$ & $\begin{array}{c}-0.002^{* * *} \\
(\mathbf{- 1 . 7 7 )}\end{array}$ & $\begin{array}{l}-0.002 \\
\mathbf{- 1 . 6 0 0}\end{array}$ & $\begin{array}{c}-0.002^{* * *} \\
\mathbf{( - 1 . 7 9 )}\end{array}$ & $\begin{array}{c}-0.002^{* * *} \\
\mathbf{( - 1 . 7 3 )}\end{array}$ & $\begin{array}{c}-0.002^{* * *} \\
\mathbf{( - 1 . 8 5 )}\end{array}$ \\
\hline Saving /GDP & $\begin{array}{c}0.17^{*} \\
\mathbf{( 4 . 5 7 )}\end{array}$ & $\begin{array}{l}0.16^{*} \\
\mathbf{( 3 . 8 4 )}\end{array}$ & $\begin{array}{l}0.18^{*} \\
\mathbf{( 4 . 5 5 )}\end{array}$ & $\begin{array}{l}0.18^{*} \\
(\mathbf{3 . 9 8})\end{array}$ & $\begin{array}{l}0.18^{*} \\
\mathbf{4 . 4 1 )}\end{array}$ & $\begin{array}{l}0.17^{*} \\
\mathbf{( 3 . 9 0 )}\end{array}$ \\
\hline Time dummies & No & Yes & No & Yes & No & Yes \\
\hline No. of Observations & 2555 & 2555 & 2185 & 2185 & 2185 & 2185 \\
\hline No. of Groups & 142 & 142 & 121 & 121 & 121 & 121 \\
\hline First order ( $p$-value $)^{1}$ & 0.00 & 0.00 & 0.00 & 0.00 & 0.00 & 0.00 \\
\hline Second order ( $p$-value $)^{2}$ & 0.207 & 0.272 & 0.19 & 0.2451 & 0.198 & 0.286 \\
\hline Sargan test ( $p$-value) & 0.644 & 0.4874 & 0.644 & 0.929 & -- & -- \\
\hline
\end{tabular}

\section{Notes}

All regressions include a constant term and are estimated by one-step system GMM except results reported in columns 5 and 6 , which are estimated by two-step system GMM with corrected standard errors. Robust $z$-values are in parentheses. *, **, and *** indicate statistical significance at 1 percent, 5 percent and 10 percent levels, respectively.

1. The null hypothesis is that the instruments are not correlated with the errors.

2. The null hypothesis is that the errors in the first difference are not serially correlated of second order. 
All the control variables have the expected effects. The results reported under columns $1-6$ show that past domestic investment robustly enhances the current domestic investment rate. The real GDP growth rate has a positive effect on the rate of domestic investment, which is consistent with the findings of previous studies. Also, the estimated coefficient on domestic saving is positive and robustly significant at the 1 percent level, suggesting that a high domestic investment rate is associated with high saving rates. Further, we find that financial development plays a critical role in determining the rate of domestic investment, although the estimated coefficient is statistically insignificant. ${ }^{7}$ On the other hand, the results show that the estimated coefficient on trade openness is negative and significant at the 1 percent level, suggesting that trade liberalization reduces domestic investment. Finally, as expected, high inflation rates discourage domestic investment, as a result of macroeconomic instability and uncertainty. The estimated coefficient on the inflation variable is negative and significant at the 10 percent level.

As mentioned above, the system-GMM estimator checks for the validity of the moment conditions by performing the Sargan/Hansen test for over-identification, and tests for serial correlation of the differenced error term. As can be seen from the corresponding $p$-values of these tests, reported at the bottom of Table 3, the null hypothesis of the validity of instruments cannot be rejected. Also, the first- and second-order serial correlation tests show that there exist negative first-order serial correlations and no evidence of second-order serial correlation in the differenced error terms.

\section{A. Robustness Checks}

The above results suggest that FDI outflows have a negative impact on domestic economic activity. In this section, five sensitivity analyses assess the robustness of this result. The first is related to resource-exporting countries. Because these countries have large foreign reserves, capital outflows are not related to market factors but are largely influenced by policy factors. Thus, to test whether the results are sensitive to those countries, oil-exporting countries and China were excluded from the sample and the model was re-estimated. The results are reported in columns 1 and 2 of Table 4. It is evident that the results are not derived from those countries. The impact of FDI outflows on domestic investment is still negative and significant at the 1 percent level, yet the estimated coefficient is smaller than that reported in Table $3{ }^{8}$

The second sensitivity check is to test whether FDI outflows are results of the political and institutional environment in those countries. This test controls for three different institutional

\footnotetext{
${ }^{7}$ In an unreported regression, credit to the private sector, instead of the M2 variable, was used as a proxy for financial development. The results do not change. Also, general government gross debt as a percentage of GDP is used to test for the debt overhang hypothesis, which is expected to have a negative impact on domestic investment. The estimated coefficient is negative but insignificant.

${ }^{8}$ Also, in different regressions, the study controls for the human capital factor by using secondary school enrollment as a percentage of total enrollment and real effective exchange rates. The results do not change.
} 
factors: political risk, using an index ranking countries on a scale of 1 (very safe) to 5 (very risky); the quality of institutions, which is captured using an index scaled from 0 (very low) to 6 (very high); and corruption level, using an index scaled from 6 (highly corrupt) to 0 (highly clean). If, after controlling for these factors, the impact of outward FDI on domestic investment changes or becomes insignificant, then it is interpreted that FDI capital flows outward because of market distortions associated with the political and institutional environment. The results of those regressions are reported under columns 3-8 of Table 4. The results still show that there is a negative relationship between outward FDI and domestic investment, suggesting that outward FDI reduces the country's domestic investment activity. ${ }^{9}$

The third robustness check is related to the nonlinearity impact of the FDI outflows on the home country's domestic investment. If the relationship between outward FDI and domestic investment is nonlinear, then the results reported above are inconsistent. Therefore, to test for the nonlinearity effect of FDI outflows, a dummy variable was created, equal to one if outflow ratios are greater than 1 percent and zero otherwise. Then, this dummy is interacted with FDI outflows and included in the benchmark equation as an additional variable. If the estimated coefficients of the interactive variables are significantly different from zero, then the relationship between outward FDI and domestic investment is indeed nonlinear. As shown in Table 5, the results reported under columns 1 and 2 show that outward FDI as a percentage of GDP not exceeding 1 percent has no effect on the home country's domestic investment; the estimated coefficient is insignificantly positive. On the other hand, outward FDI as a percentage of GDP exceeding 1 percent has a significant impact on domestic investment. These results suggest that domestic investment responds to FDI outflows in a nonlinear manner.

The third sensitivity check is to test whether the relationship between FDI and domestic investment depends on the depth of the home country's financial development. To test this hypothesis, outward FDI as a percentage of GDP is interacted with the financial development variable (M2), and this new variable is included in the benchmark equation as an additional variable. If the coefficient of this interaction term is negative and significant, then it is interpreted to mean that outward FDI negatively affects domestic investment levels through financial development. As can be seen from the results reported in columns 3 and 4 of Table 4, the estimated coefficient of the interaction term is negative, though insignificant. This result suggests that the negative relationship between outward FDI and domestic investment is not conditional on the level of the home country's financial development.

\footnotetext{
9 The results reported under columns 5-8 should be interpreted with caution. The first- and second- order serial correlation tests show that there exist negative first-order serial correlations and evidence of second-order serial correlation in the differenced error terms. This makes the results inconsistent.
} 
The last robustness check explores alternative estimation methods. Three different methods are used, namely Pooled OLS (POLS), Within Groups (WG) and first-differenced GMM estimators. In the presence of the individual-specific effects, OLS estimates of the coefficient on the lagged dependent variable are biased upward (Hsiao, 2003: p. 74) while the WG estimates of the coefficient on the lagged dependent variable are biased downwards in short panels (Nickell, 1981). The first-differenced GMM estimator has been found to have poor finite sample bias and poor precision when the lagged levels of the series are weak instruments for the first differences, especially for variables that are close to a random walk (Blundell and Bond, 1998). Equation (6) is re-estimated using those three estimators. The results are reported in Table 6: the significance of the negative impact of FDI outflows on the home country's domestic investment remains unchanged throughout all the alternative specifications.

\section{CONCLUSION}

This study provides new empirical evidence of the effects of outward FDI on the domestic investment rate in developing countries. While there are a considerable number of empirical studies on the effects of developed countries' outward FDI on their own domestic economic activity, to our knowledge, this is a first such study on the relationship between outward FDI and domestic investment in developing and transition economies.

From a theoretical standpoint, the effect of outward FDI on the home country's domestic investment rate depends on the motives for investing abroad. Because different types of FDI cannot be distinguished by motive, the effects of FDI on the home country's domestic investment become an empirical question. Thus, the main objective of this study was to test empirically the link between outward FDI and the country's rate of domestic investment, using data from 121 developing home countries over the period 1990-2010. This relationship is modeled in a partial adjustment framework and estimated using the system-GMM estimator to cope with the possible endogeneity of the independent variables, especially outward and inward FDI.

The empirical results show a robust negative relationship between outward FDI and the rate of domestic investment. A one percentage point increase in outward FDI leads to a reduction of about 29 percent in domestic investment. The results confirm to some extent those found by the empirical studies cited above. These results may be driven by the presence of distortions and domestic bottlenecks in the local economies, such as scarcity of capital and imperfect financial markets. The types of policy prescription needed to address these distortions could help to mitigate the negative impact of outward FDI, and, in some cases, to boost domestic saving and investment. 


\section{References}

Agosin, M., and R. Mayer (2000), "Foreign Investment in Developing Countries: Does it Crowd in Domestic Investment?” UNCTAD Discussion Paper No. 146 (Geneva: United Nations Conference on Trade and Development).

Agènor, P., (2004), “the Economics of Adjustment and Growth”, second edition, Harvard University Press,

Al-Sadig, A., (2012), "the Effects of Foreign Direct Investment on Private Domestic Investment: Evidence From Developing Countries", Empirical Economics, pp. 1-9 doi:10.1007/s00181-012-0569-1.

Andersen, P.S. and P. Hainaut (1998), "Foreign Direct Investment and Employment in the Industrial Countries”, BIS Working Papers No. 61, (Basle: Bank for International Settlements).

Arellano, M. and O. Bover (1995), “Another Look at the Instrumental Variable Estimation of Error-Components Models”, Journal of Econometrics, 68: pp. 29-52.

Arellano, M. and S. Bond (1991), "Some Tests of Specification for Panel Data: Monte Carlo Evidence and an Application to Employment Equations", The Review of Economic Studies, 58(2): pp. 277-297.

Baltagi, B., (2005), Econometric Analysis of Panel Data, 3rd edition (Hoboken, NJ: Wiley).

Blejer, M., and M. Khan, (1984), "Government Policy and Private Investment in Developing Countries” IMF Staff Papers, 31(2): pp.379-403 (Washington: International Monetary Fund).

Blundell, R. and S. Bond, (1998), "Initial Conditions and Moment Restrictions in Dynamic Panel Data Models", Journal of Econometrics, 87: pp. 115-143.

Bosworth, B. and S. Collins (1999), "Capital Flows to Developing Economies: Implications for Saving and Investment”, Brookings Papers on Economic Activity, 1999(1): 143-180 (Washington: Brookings Institution).

Desai, M.A., C. F. Foley, and J. R. Hines, Jr., (2005), “Foreign Direct Investment and the Domestic Capital Stock", American Economic Review: 95 (2) pp. 33-38.

Dunning, J., (1993), Multinational Enterprises and the Global Economy, (Cheltenham, UK: Edward Elgar Publishing).

Feldstein, M., (1995), "The Effects of Outbound Foreign Direct Investment on the Domestic Capital Stock" , In: Feldstein, M., J.R. Hines Jr., and R.G. Hubbard (eds.). The Effects of Taxation on Multinational Corporations. (Chicago: University of Chicago Press), pp. 43-63. 
Feldstein, M., and C. Horioka, (1980), "Domestic Savings and International Capital flows", Economic Journal 90: pp. 314-329.

Gibney, M., Cornett, L., \& Wood, R., (2012), Political Terror Scale 1976-2011: http://www.politicalterrorscale.org/.

Greene, J., and D. Villanueva, (1991), "Private Investment in Developing Countries", IMF Staff Papers, 38(1): pp. 33-58 (Washington: International Monetary Fund).

Hejazi, W., and P. Pauly, (2003), "Motivations for FDI and Domestic Capital Formation”, Journal of International Business Studies 34: pp. 282-289.

Herzer, D., and M. Schrooten, (2007), "Outward FDI and Domestic Investment", DIW Discussion Paper 679. (Berlin: Deutsches Institut für Wirtschaftsforschung).

Hsiao, C., (2003), Analysis of Panel Data, second edition. Cambridege, UK: Cambridege University.

International Monetary Fund (2012), World Economic Outlook database.

Ndikumana, L., (2000), "Financial Determinants of Domestic Investment in Sub-Saharan Africa: Evidence from Panel Data," World Development, 28(2): pp. 381-400.

Nickell, S., (1981), "Biases in Dynamic Models with Fixed Effects,” Econometrica, 49(6): pp. 1417-1426.

Oshikoya, T., (1994), "Macroeconomic Determinants of Domestic Private Investment in Africa: An Empirical Analysis", Economic Development and Cultural Change, 42: pp. 573596.

Sauramo, P., (2008), "Does Outward Foreign Direct Investment Reduce Domestic Investment? Macro-evidence from Finland", Labour Institute for Economic Research, Discussion Papers No. 239 (Helsinki).

Servén, L., and A. Solimano, (1993), "Debt Crisis, Adjustment Policies and Capital Formation in Developing Countries: Where Do We Stand?" World Development, 21(1): pp. 127140.

Stevens, G.V.G. and Lipsey, R.E. (1992), "Interactions between Domestic and Foreign Investment", Journal of International Money and Finance 11(1): pp. 40-62.

The World Bank Groups (2012), World Development Indicators.

UNCTAD (2012), World Investment Report, Towards a new Generation of Investment Policies, (Geneva: United Nations Conference on Trade and Development).

Van Loo, F., (1977), “The Effects of Foreign Direct Investment on Investment in Canada", Review of Economics and Statistics, 59 (4): pp. 474-481.

Wai, T.U. and C.H. Wong, (1982), "Determinants of Private Investment in Developing Countries", Journal of Development Studies, 19(1): pp. 19-36. 
Xu, G., and R. Wang, (2007), “The Effect of Foreign Direct Investment on Domestic Capital Formation, Trade and Economic Growth in a Transition Economy: Evidence from China." Global Economy Journal, 7 (2): pp. 1-21. 


\section{APPENDIX}

Table 4. Domestic Investment and Capital Flows: Political Environment

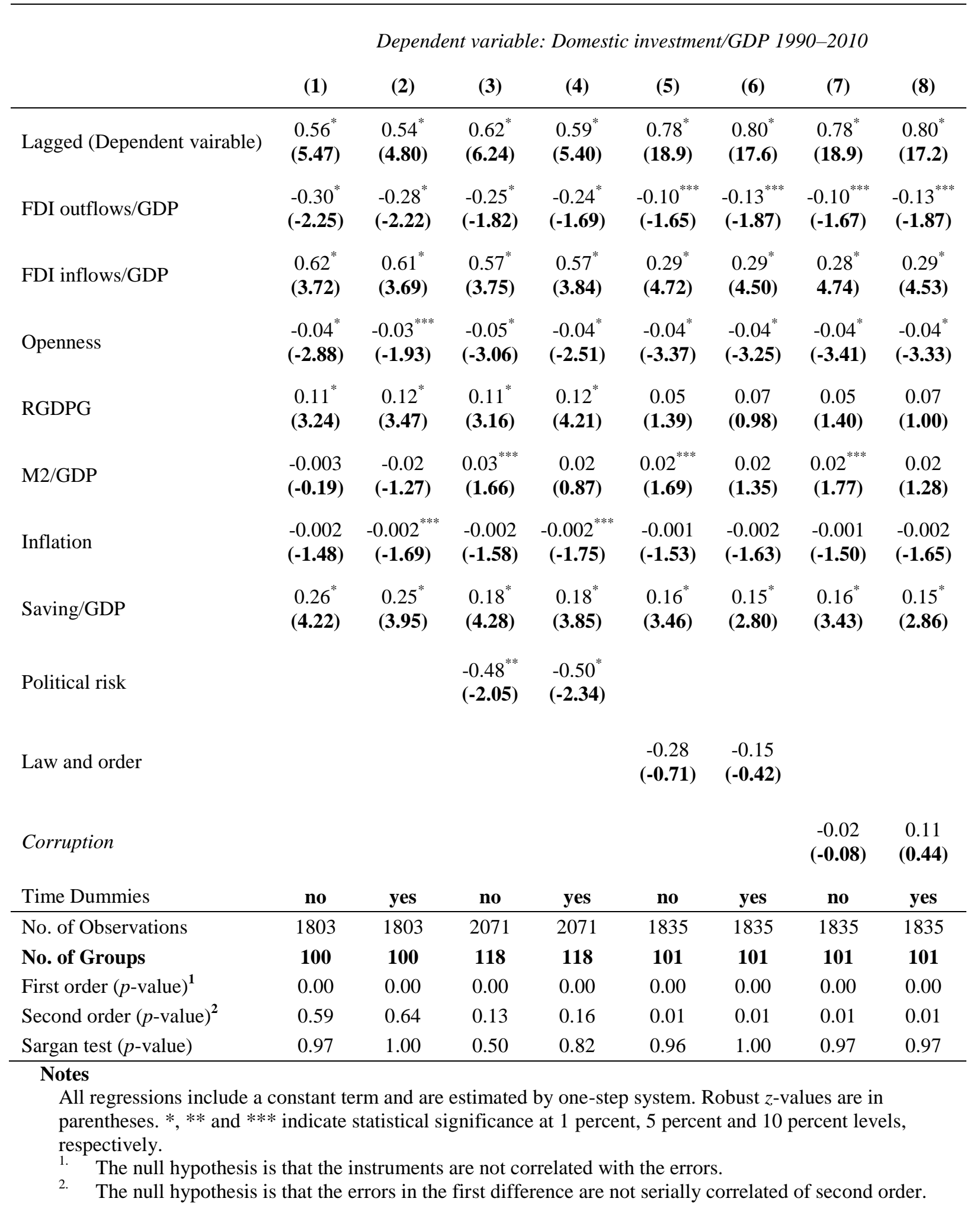


Table 5. Domestic Investment and Capital Flows: Non-linearity Relations

Dependent variable: Domestic Investment/GDP: 1990-2010

Independent Variables

Lagged dependent variable
(FDI ouflows/GDP)* dummy $=1$
if FDI outflows $<=1 \%$
(FDI ouflows/GDP)* dummy $=1$
if FDI outflows $>1 \%$
FDI ouflows/GDP
(FDI outflows/GDP)*(M2/GDP)

FDI inflows/GDP

Openness

Real GDP growth rate

M2/GDP

Inflation

Saving /GDP

Time dummies

No. of Observations

No. of Groups

First order $(p \text {-value })^{1}$

Second order $(p \text {-value })^{2}$

Sargan test ( $p$-value)
(1)

$\begin{array}{cc}0.62^{*} & 0.60^{*} \\ \mathbf{( 5 . 8 8 )} & \mathbf{( 5 . 3 8 )} \\ 0.04 & 0.01 \\ (\mathbf{0 . 2 3}) & \mathbf{( 0 . 0 4 )} \\ -0.34^{*} & -0.33^{*} \\ \mathbf{( - 2 . 5 3 )} & \mathbf{( - 2 . 6 8 )}\end{array}$

(3)

(4)

$\begin{array}{cc}0.62^{*} & 0.60^{*} \\ \mathbf{( 5 . 8 7 )} & \mathbf{( 5 . 3 8 )}\end{array}$

(-2.68)

$\begin{array}{cc}-0.23 & -0.24 \\ \mathbf{( - 1 . 4 4 )} & \mathbf{( - 1 . 5 0 )} \\ -0.0004 & -0.0004 \\ \mathbf{( - 0 . 5 2 )} & \mathbf{( - 0 . 4 6 )}\end{array}$

$\begin{array}{cccc}0.55^{*} & 0.55^{*} & 0.55^{*} & 0.55^{*} \\ \mathbf{( 3 . 6 7 )} & \mathbf{( 3 . 8 6 )} & \mathbf{( 3 . 6 4 )} & \mathbf{( 3 . 8 2 )} \\ -0.04^{*} & -0.03^{*} & -0.04^{*} & -0.03^{*} \\ \mathbf{( - 3 . 0 5 )} & \mathbf{( - 2 . 3 1 )} & \mathbf{( - 3 . 1 2 )} & \mathbf{( - 2 . 3 3 )}\end{array}$

$0.11^{*} \quad 0.13^{*} \quad 0.11^{*} \quad 0.13^{*}$

$\begin{array}{llll}(2.68) & \mathbf{( 4 . 1 9 )} \quad \mathbf{( 2 . 7 3 )} & \mathbf{( 4 . 2 4 )}\end{array}$

$\begin{array}{llll}0.01 & 0.00 & 0.01 & 0.00\end{array}$

$\begin{array}{llll}(\mathbf{0 . 9 3}) & (\mathbf{0 . 1 6}) & \mathbf{0 . 9 2} & \mathbf{0 . 1 1}\end{array}$

$0.0001 \quad 0.0001^{* * *} \quad 0.0001 \quad 0.0001^{* * *}$

$\begin{array}{llll}\mathbf{( - 1 . 6 1 )} & \mathbf{( - 1 . 8 0 )} \quad \mathbf{( - 1 . 6 0 )} \quad \mathbf{( - 1 . 7 9 )}\end{array}$

$0.18^{*} \quad 0.18^{*} \quad 0.18^{*} \quad 0.18^{*}$

$\begin{array}{llll}(4.57) & (4.00) & (4.52) & \text { (3.95) }\end{array}$

\begin{tabular}{cccc} 
no & yes & no & yes \\
\hline 2185 & 2185 & 2185 & 2185 \\
$\mathbf{1 2 1}$ & $\mathbf{1 2 1}$ & $\mathbf{1 2 1}$ & $\mathbf{1 2 1}$ \\
0.00 & 0.00 & 0.00 & 0.00 \\
0.18 & 0.23 & 0.20 & 0.25 \\
0.65 & 0.95 & 0.65 & 0.94
\end{tabular}

Notes

All regressions include a constant term and are estimated by one-step system GMM. Robust $z$-values are in parentheses. *, ** and *** indicate statistical significance at 1percent, 5percent and 10percent levels, respectively.

1. The null hypothesis is that the instruments are not correlated with the errors.

2. The null hypothesis is that the errors in the first difference are not serially correlated of second order. 
Table 6. Domestic Investment and Capital Flows: Alternative Estimation Methods

\begin{tabular}{|c|c|c|c|c|c|c|}
\hline \multirow[b]{2}{*}{ Independent Variables } & \multicolumn{5}{|c|}{ Dependent variable: Domestic Investment/GDP: 1990-2010 } & \multirow[b]{2}{*}{ DGMM } \\
\hline & POLS & POLS & WG & WG & DGMM & \\
\hline Lagged (Dependent variable) & $\begin{array}{l}0.75^{*} \\
(\mathbf{2 2 . 0})\end{array}$ & $\begin{array}{l}0.75^{*} \\
(\mathbf{2 1 . 5 )}\end{array}$ & $\begin{array}{c}0.62^{*} \\
(\mathbf{1 2 . 6})\end{array}$ & $\begin{array}{c}0.62^{*} \\
(\mathbf{1 2 . 4})\end{array}$ & $\begin{array}{l}0.55^{*} \\
(\mathbf{3 . 7 6})\end{array}$ & $\begin{array}{l}0.61^{*} \\
(\mathbf{4 . 5 5 )}\end{array}$ \\
\hline FDI outflows /GDP & $\begin{array}{l}-0.13^{*} \\
(-2.67)\end{array}$ & $\begin{array}{l}-0.14^{*} \\
(-2.92)\end{array}$ & $\begin{array}{l}-0.14^{* *} \\
\mathbf{( - 1 . 9 8 )}\end{array}$ & $\begin{array}{c}-0.16^{*} \\
(-2.15)\end{array}$ & $\begin{array}{c}-0.14 \\
\mathbf{( - 1 . 4 2 )}\end{array}$ & $\begin{array}{l}-0.21^{* *} \\
\mathbf{( - 1 . 9 3 )}\end{array}$ \\
\hline FDI inflows / GDP & $\begin{array}{l}0.34^{*} \\
(\mathbf{6 . 7 3})\end{array}$ & $\begin{array}{l}0.36^{*} \\
(\mathbf{6 . 8 9})\end{array}$ & $\begin{array}{l}0.41^{*} \\
\mathbf{( 3 . 9 1 )}\end{array}$ & $\begin{array}{l}0.42^{*} \\
(\mathbf{4 . 0 4})\end{array}$ & $\begin{array}{l}0.48^{*} \\
\mathbf{( 3 . 3 1 )}\end{array}$ & $\begin{array}{l}0.53^{*} \\
\mathbf{( 3 . 7 3 )}\end{array}$ \\
\hline Openness & $\begin{array}{c}-0.01^{*} \\
(-\mathbf{5 . 0 0 )}\end{array}$ & $\begin{array}{l}-0.01^{*} \\
(-4.75)\end{array}$ & $\begin{array}{l}-0.04^{*} \\
\mathbf{( - 4 . 1 6 )}\end{array}$ & $\begin{array}{c}-0.03^{*} \\
(-3.77)\end{array}$ & $\begin{array}{l}-0.11^{*} \\
(-2.49)\end{array}$ & $\begin{array}{c}-0.03 \\
\mathbf{( - 0 . 6 1 )}\end{array}$ \\
\hline RGDPG & $\begin{array}{c}0.04 \\
(\mathbf{0 . 8 0})\end{array}$ & $\begin{array}{c}0.05 \\
(\mathbf{0 . 8 3})\end{array}$ & $\begin{array}{l}0.07^{*} \\
\mathbf{( 3 . 4 3 )}\end{array}$ & $\begin{array}{l}0.07^{*} \\
\mathbf{3 . 4 9 0}\end{array}$ & $\begin{array}{c}0.11 \\
\mathbf{( 1 . 5 9 )}\end{array}$ & $\begin{array}{l}0.1^{* * * *} \\
(\mathbf{1 . 6 7 )}\end{array}$ \\
\hline M2 /GDP & $\begin{array}{l}0.001 \\
(\mathbf{0 . 3 7})\end{array}$ & $\begin{array}{l}0.002 \\
(\mathbf{0 . 5 6 )}\end{array}$ & $\begin{array}{c}0.001 \\
\mathbf{( - 0 . 0 4 )}\end{array}$ & $\begin{array}{l}0.006 \\
\mathbf{0 . 4 1 0}\end{array}$ & $\begin{array}{c}0.03 \\
(\mathbf{1 . 2 0})\end{array}$ & $\begin{array}{c}0.04 \\
\mathbf{( 1 . 3 0 )}\end{array}$ \\
\hline Inflation & $\begin{array}{c}-0.001^{\text {**** }} \\
\mathbf{( - 1 . 7 4 )}\end{array}$ & $\begin{array}{c}-0.001^{* *} \\
(-\mathbf{2 . 1 4})\end{array}$ & $\begin{array}{c}-0.001^{* * *} \\
\mathbf{( - 1 . 8 4 )}\end{array}$ & $\begin{array}{c}-0.001^{* *} \\
-\mathbf{2 . 4 0}\end{array}$ & $\begin{array}{l}-0.002 \\
\mathbf{( - 1 . 5 9 )}\end{array}$ & $\begin{array}{c}-0.003^{* * *} \\
(\mathbf{- 1 . 7 7 )}\end{array}$ \\
\hline Saving/GDP & $\begin{array}{l}0.10^{*} \\
\mathbf{( 5 . 5 0 )}\end{array}$ & $\begin{array}{l}0.10^{*} \\
\mathbf{( 5 . 4 0 )}\end{array}$ & $\begin{array}{l}0.12^{*} \\
(\mathbf{3 . 6 3})\end{array}$ & $\begin{array}{l}0.12^{*} \\
(\mathbf{3 . 3 9})\end{array}$ & $\begin{array}{l}0.20^{*} \\
\mathbf{( 3 . 3 2 )}\end{array}$ & $\begin{array}{l}0.21^{*} \\
\mathbf{( 3 . 3 4 )}\end{array}$ \\
\hline Constant & $\begin{array}{c}3.5^{*} \\
(\mathbf{6 . 4 5})\end{array}$ & $\begin{array}{c}3.4^{*} \\
(\mathbf{4 . 4 0 )}\end{array}$ & $\begin{array}{c}8.1^{*} \\
(6.12)\end{array}$ & $\begin{array}{c}7.8^{*} \\
(4.77)\end{array}$ & $\begin{array}{l}12.3^{*} \\
(\mathbf{3 . 3 6})\end{array}$ & $\begin{array}{c}5.4^{*} \\
(\mathbf{0 . 9 4})\end{array}$ \\
\hline Time Dummies & no & yes & no & yes & no & yes \\
\hline R-sq: Within & -- & -- & 0.58 & 0.59 & -- & -- \\
\hline Between & -- & -- & 0.89 & 0.91 & -- & -- \\
\hline Overall & 0.78 & 0.78 & 0.75 & 0.77 & & \\
\hline No. of Observations & 2185 & 2185 & 2185 & 2185 & 2056 & 2056 \\
\hline No. of Groups & 121 & 121 & 121 & 119 & 119 & 119 \\
\hline
\end{tabular}

\footnotetext{
Notes
}

POLS: Pool OLS, WG; within Group estimator, DGMM: First-differenced GMM. Robust $t$-values are in parentheses.*, ** and $* * *$ indicate statistical significance at 1 percent, 5 percent and 10 percent levels, respectively. 
Table A. Correlation Matrix

\begin{tabular}{lcccccccc}
\hline Variables & $\mathbf{1}$ & $\mathbf{2}$ & $\mathbf{3}$ & $\mathbf{4}$ & $\mathbf{5}$ & $\mathbf{6}$ & $\mathbf{7}$ & $\mathbf{8}$ \\
\hline DI & 1.00 & & & & & & & \\
OFDI & 0.02 & 1.00 & & & & & & \\
IFDI & 0.37 & 0.39 & 1.00 & & & & & \\
RGDPG & 0.33 & 0.01 & 0.24 & 1.00 & & & & \\
M2 & 0.08 & 0.41 & 0.14 & -0.09 & 1.00 & & & \\
Inflation & -0.01 & -0.03 & -0.04 & -0.14 & -0.07 & 1.00 & & \\
Saving & 0.43 & 0.15 & 0.02 & 0.17 & 0.22 & -0.01 & 1.00 & \\
Openness & 0.22 & 0.39 & 0.47 & 0.14 & 0.34 & -0.06 & 0.25 & 1.00 \\
\hline
\end{tabular}

Table B: Descriptive Statistics

\begin{tabular}{lccccc}
\hline Sample: 142 countries: 1990-2010 & & & & Min & Max \\
\hline Variables & Obs & Mean & Std. Dev & 1.37 & 115.1 \\
\hline DI & 2555 & 22.94 & 8.66 & -24.9 & 49.86 \\
OFDI & 2555 & 1.17 & 3.61 & -15.6 & 90.46 \\
IFDI & 2555 & 3.72 & 5.67 & -27.1 & 149.97 \\
RGDPG & 2555 & 4.06 & 5.68 & 4.22 & 323.58 \\
M2 & 2555 & 52.43 & 41.84 & -11.6 & 7481.6 \\
Inflation & 2555 & 22.51 & 207.94 & -78.9 & 75.45 \\
Saving & 2555 & 20.24 & 11.41 & 0.00 & 460.4 \\
Openness & 2555 & 84.5 & 51.8 & 1.00 & 5.00 \\
Political risk & 2214 & 2.67 & 1.02 & 0.00 & 6.00 \\
Law and order & 1945 & 3.39 & 1.20 & 0.00 & 5.00 \\
Corruption & 1945 & 2.54 & 0.95 & 4.5 & 162.3 \\
Schooling & 2494 & 69.1 & 32.7 & 37.5 & 1025.3 \\
REER & 2734 & 106.6 & 36.1 & & \\
\hline
\end{tabular}

Notes

DI: Domestic investment, OFDI: outward FDI, IFDI: inward FDI, RGDPG: real GDP growth rate, M2: Broad money supply, REER: real effective exchange rate. With the exception of RGDPG, inflation rate political risk, law and order, and corruption, all variables are as a percent of GDP 


\section{Definitions of Variables and Their Sources}

\begin{tabular}{|c|c|c|}
\hline Variables & Definition & Source \\
\hline DI & Gross capital formation & World Economic Outlook database, 2012 \\
\hline RGDPG & Real GDP growth & World Economic Outlook database, 2012 \\
\hline Inflation & Annual inflation rate & World Economic Outlook database, 2012 \\
\hline Saving & Gross national saving & World Economic Outlook database, 2012 \\
\hline Debts & $\begin{array}{l}\text { General government gross debt as \% of } \\
\text { GDP }\end{array}$ & World Economic Outlook database, 2012 \\
\hline M2 & $\begin{array}{l}\text { Money and quasi money (M2) as \% of } \\
\text { GDP }\end{array}$ & The World Bank's World development Indicators \\
\hline Openness & Exports and Imports as a \% of GDP & The World Bank's World development Indicators \\
\hline Credit & $\begin{array}{l}\text { Domestic credit to private sector } \% \text { of } \\
\text { GDP) }\end{array}$ & The World Bank's World development Indicators \\
\hline Schooling & Secondary school enrollment $\%$ of total & The World Bank's World development Indicators \\
\hline REER & Real effective exchange rate $(2005=100)$ & The World Bank's World development Indicators \\
\hline FDI inflows & Foreign direct investment inflows & UNCTAD’s World Investment Report 2012 \\
\hline FDI outflows & Foreign direct investment Outflows & UNCTAD's World Investment Report 2012 \\
\hline Political Risk & $\begin{array}{l}\text { Political Terror Scale-US State } \\
\text { Department, } 1 \text { (very low), and } 5 \text { (very } \\
\text { high) }\end{array}$ & http://politicalterrorscale.org/ \\
\hline $\begin{array}{l}\text { Quality of } \\
\text { Institutions }\end{array}$ & $\begin{array}{l}\text { Index measuring law and order ranging } \\
\text { from } 0 \text { (very low) to } 6 \text { (very high) }\end{array}$ & $\begin{array}{l}\text { International Country Risk Guide, the Political Risk } \\
\text { Groups }\end{array}$ \\
\hline Corruption level & $\begin{array}{l}\text { Corruption level } 0 \text { (very low) to } 6 \text { (very } \\
\text { high) }\end{array}$ & $\begin{array}{l}\text { International Country Risk Guide, the Political Risk } \\
\text { Groups }\end{array}$ \\
\hline
\end{tabular}




\section{Country Sample}

Albania, Algeria, Angola, Antigua and Barbuda, Argentina, Armenia, Azerbaijan, Australia*, Austria*, Bahamas, Bahrain, Bangladesh, Barbados, Belarus, Belgium*, Bolivia, Belize, Benin, Bosnia and Herzegovina, Botswana, Brazil, Brunei Darussalam, Bulgaria, Burkina Faso, Burundi, Cambodia, Cameroon, Canada*, Cape Verde, Central African Republic, Chad, Chile, China, Colombia, Comoros, Congo, Rep., Congo, Dem. Rep., Costa Rica, Côte d'Ivoire, Croatia, Cyprus, Czech Republic, Denmark*, Dominican Republic, Ecuador, Egypt, El Salvador, Estonia, Equatorial Guinea, Fiji, Finland*, France*, Gabon, Georgia, Hong Kong Kazakhstan, Kyrgyz Republic, Lao PDR, Latvia, Lesotho, Lithuania, Germany*, Ghana, Greece*, Guatemala, Guinea, Guinea-Bissau, Guyana, Haiti, Hungary, Iceland*, India, Indonesia, Iran, Ireland*, Italy*, Jamaica, Japan*, Jordan, Kenya, Korea, Rep. of, Kuwait, Lebanon, Liberia, Libya, Madagascar, Malawi, Malaysia, Mali, Malta, Mauritania, Mauritius, Mexico, Mongolia, Morocco, Mozambique, Namibia, Netherlands*, New Zealand*, Nicaragua, Niger, Nigeria, Norway*, Oman, Pakistan, Panama, Papua New Guinea, Paraguay, Peru, Philippines, Poland, Portugal*, Qatar, Romania, Russian Federation, Saudi Arabia ,Senegal, Seychelles, Sierra Leone, Singapore, Slovak Republic, South Africa, Spain*, Sri Lanka, Sudan, Suriname, Swaziland, Sweden*, Switzerland*, Syria, Tanzania, Thailand, Togo, Tonga, Trinidad and Tobago, Tunisia, Turkey, Uganda, United Arab Emirates, Ukraine, Inited Kingdom*, United States*, Uruguay, Vanuatu, Venezuela, Vietnam, Zambia, Zimbabwe. ${ }^{10}$

$10 *$ Developed countries 